\title{
On a Pterosaur Jaw from the Upper Jurassic of Tendaguru (Tanzania)
}

\author{
David M. Unwin ${ }^{1} \&$ Wolf-Dieter Heinrich ${ }^{1}$
}

With 3 figures

\begin{abstract}
A short section of a mandibular symphysis is the first cranial fossil of a pterosaur to be reported from the Upper Jurassic of Tendaguru, Tanzania. It is made the holotype of a new dsungaripteroid pterosaur, Tendaguripterus recki n. gen. n. sp. All previously named pterosaur taxa from Tendaguru are shown to be nomina dubia. The pterosaur assemblage from Tendaguru contains a 'rhamphorhynchoid', as well as the dsungaripteroid, and is similar in its systematic composition to other Late Jurassic pterosaur assemblages from Laurasia. The diversity and broad distribution of dsungaripteroids in the Late Jurassic suggests that the group was already well established by this time.
\end{abstract}

Key words: Tendaguru, Tanzania, Upper Jurassic, pterosaur, Pterodactyloidea, Dsungaripteroidea.

\section{Zusammenfassung}

Der erste Schädelrest eines Flugsauriers aus dem Oberjura von Tendaguru in Tansania wird beschrieben. Bei dem Fundstück handelt es sich um ein bezahntes Unterkieferbruchstück aus der Symphysenregion. Der Fund gehört zu einem neuen Taxon, das als Tendaguripterus recki $\mathrm{n}$. gen. $\mathrm{n}$. sp. bezeichnet und zur Überfamilie Dsungaripteroidea gestellt wird. Alle zuvor aus den Tendaguru-Schichten beschriebenen Taxa werden als nomina dubia angesehen. In Tendaguru sind Verteter der ,Rhamphorhynchoidea und Dsungaripteroidea nachgewiesen. Diese systematische Zusammensetzung ist derjenigen anderer Flugsaurier-Vergesellschaftungen der späten Jura-Zeit ähnlich. Die Vielfalt und die weite Verbreitung der Dsungaripteroidea in Laurasia läßt darauf schließen, daß sich diese Flugsauriergruppe bereits in der späten Jura-Zeit erfolgreich durchgesetzt hatte.

Schlüsselwörter: Tendaguru, Tansania, Oberjura, Flugsaurier, Pterodactyloidea, Dsungaripteroidea.

\section{Introduction}

African pterosaur remains are exceptionally rare. A few isolated bones have been found at various Cretaceous localities (Swinton 1948, Monteillet et al. 1982, Kellner and Mader 1996, Mader and Kellner 1997, 1999, Sereno et al. 1998, Martill pers comm. 1999), but only one location, Tendaguru, has yielded Jurassic material.

Most of the pterosaur fossil remains from Tendaguru were collected from the Upper Saurian beds by the German led expeditions of 1909 to 1913 , and are currently housed in the Museum für Naturkunde of the Humboldt University, Berlin (MfNHUB). The British expeditions of 1924-1931 also collected a few pterosaur bones, now housed in the Natural History Museum, London. The first mention of pterosaur bones was by Janensch (1914a: 82) in his report on the vertebrate fauna of the Tendaguru Beds, and it was supposed, on the basis of size differences, that they represented two different taxa (Stremme cited in Janensch, 1914a). Parkinson (1930: 145) also mentioned pterosaur bones in his account of the British expeditions to Tendaguru. Reck (1931) published a short account of the material in the MfNHUB collections in which he described a few of the more complete and better preserved bones and designated some of them as holotypes for four new species of pterosaur: 'Rhamphorhynchus tendagurensis', 'Pterodactylus maximus', 'Pterodactylus brancai', and 'Pterodactylus arningi'. Subsequently, Galton (1980) published descriptions of tibiotarsi from Tendaguru and assigned 'Pterodactylus brancai' Reck, to Dsungaripterus on the basis of similarities between the African and Chinese material.

At present, all Tendaguru pterosaur taxa are based on isolated elements from the fore and hind limbs. It is rare, however, for such material

\footnotetext{
1 Museum für Naturkunde, Institut für Paläontologie, Invalidenstraße 43, D-10115 Berlin, Germany. Received January 1999, accepted March 1999
} 
to exhibit characters that are diagnostic at low taxonomic levels and Wellnhofer (1978) has already raised doubts regarding the validity of some of the Tendaguru taxa. By contrast, skull remains and, in particular, the jaws and dentition, often exhibit distinctive characters that are critical for diagnosing species and genera (Wellnhofer 1978, 1991). Recently, during preparation of a block of matrix from the Middle Saurian bed, as part of a programme of microvertebrate sampling, one of us (W.-D. H.) found a small bone that was preliminarily identified by M. Howgate, London (unpublished note of May 2, 1986, Catalogue of Fossil Reptiles, Institute of Paleontology, MfNHUB) as a lower jaw fragment of a pterodactyloid pterosaur bearing four teeth. The block was treated with acetic acid to free the fossil from the matrix and preparation was completed by H.-H. Krueger (MfNHUB) who employed mechanical preparation to remove remaining sediment adhering to the jaw.

Here we describe this specimen and comment on its significance for the systematics of pterosaur remains from Tendaguru.

\section{Abbreviations}

BSP, Bayerische Staatssammlung für Paläontologie, München; GTE, German Tendaguru Expedition; MB, Museum für Naturkunde, Berlin; MGUH, Geological Museum, University of Copenhagen; NMING, National Museum of Ireland, Geological Section.

\section{Geology, localities and taphonomy}

Geology: The Tendaguru Beds, well known for their extensive dinosaur assemblage, outcrop in south-eastern Tanzania (Fig. 1). Janensch (1914b) gave a detailed description of the sedimentary succession, dividing it into Lower, Middle, and Upper Saurian Beds, which were separated by three marine sandstone units: the Nerinea Bed, the Trigonia smeei Bed, and the Trigonia schwarzi Bed (Fig. 1D). Transitional deposits between the Saurian beds and the marine units were formally recognised as the Transitional Sands (Übergangsschichten) (see Heinrich this volume, a).

The majority of pterosaur remains appear to have been recovered from the Upper Saurian Bed and the Transitional Sands at the base of the Upper Saurian Bed (Reck 1931). They were also found in the Middle Saurian Bed, but were isolated and not so abundant as in the Upper Saurian Bed. The Middle and Upper Saurian beds together with the intervening Transitional Sands are generally considered to be Kimmeridgian to Tithonian (e.g., Aitken 1961, Russell et al. 1980). Pterosaurs do not appear to have been recovered from the Lower Saurian Bed, or from the three marine units, but this may be due, at least in part, to collecting bias.

The pterosaur localities: Pterosaurs have been found at a number of sites in the Tendaguru area (Fig. 1B). These are as follows:

Site $\mathrm{Jg}(\mathrm{Wj})$ : located $2.3 \mathrm{~km}$ north-north-west of Tendaguru hill, excavations began at this site in 1910 and continued in 1911 and 1912. The site was most intensively collected in 1912, under the direction of $\mathrm{H}$. Reck, and it seems likely that the sediment that yielded the pterosaur material described below was collected during this period.

Site 69a: Reck (1931) does not give the exact location of this site, but it was situated south of Tendaguru Hill, approximately at the same position as the Fraas camp in 1908. The locality, which is quoted in the GTE-field catalogue (p. 133) as 'Graben mit Vogelknochen' (trench with bird bones), produced fossil material from a horizon high in the Upper Saurian Bed (Reck 1931:324) and is the type locality for 'Rhamphorhynchus tendagurensis'.

Site B: This locality, the type locality of 'Pterodactylus maximus' (Reck 1931: 328-330) was situated about $1 \mathrm{~km}$ south-south-east of Tendaguru Hill and produced remains from the Upper Saurian Bed.

Site MD: This locality, indicated by Janensch in his site map published in 1925, was situated about $2 \mathrm{~km}$ north-east of Tendaguru Hill. Here, in 1912, sediments of the Transitional Sands at the base of the Upper Saurian Bed produced the type material of 'Pterodactylus brancai' and many other bones and teeth of pterosaurs which were found relatively close to a well preserved vertebral column of Barosaurus africanus (Reck 1931).

Site IV: This excavation, in sediments of the Upper Saurian Bed, was situated about $1 \mathrm{~km}$ south-south-east of Tendaguru Hill, close to Site $\mathrm{B}$, and is the type locality of 'Pterodactylus arningi' (Reck 1931).

Site T: This pterosaur locality is indicated on the site map by Janensch (1925), but was not mentioned by Reck (1931). 


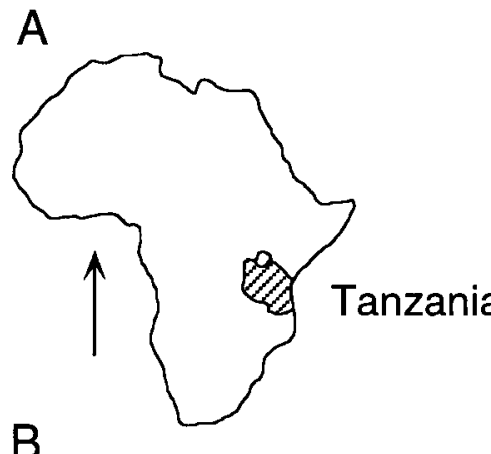

$\mathrm{B}$
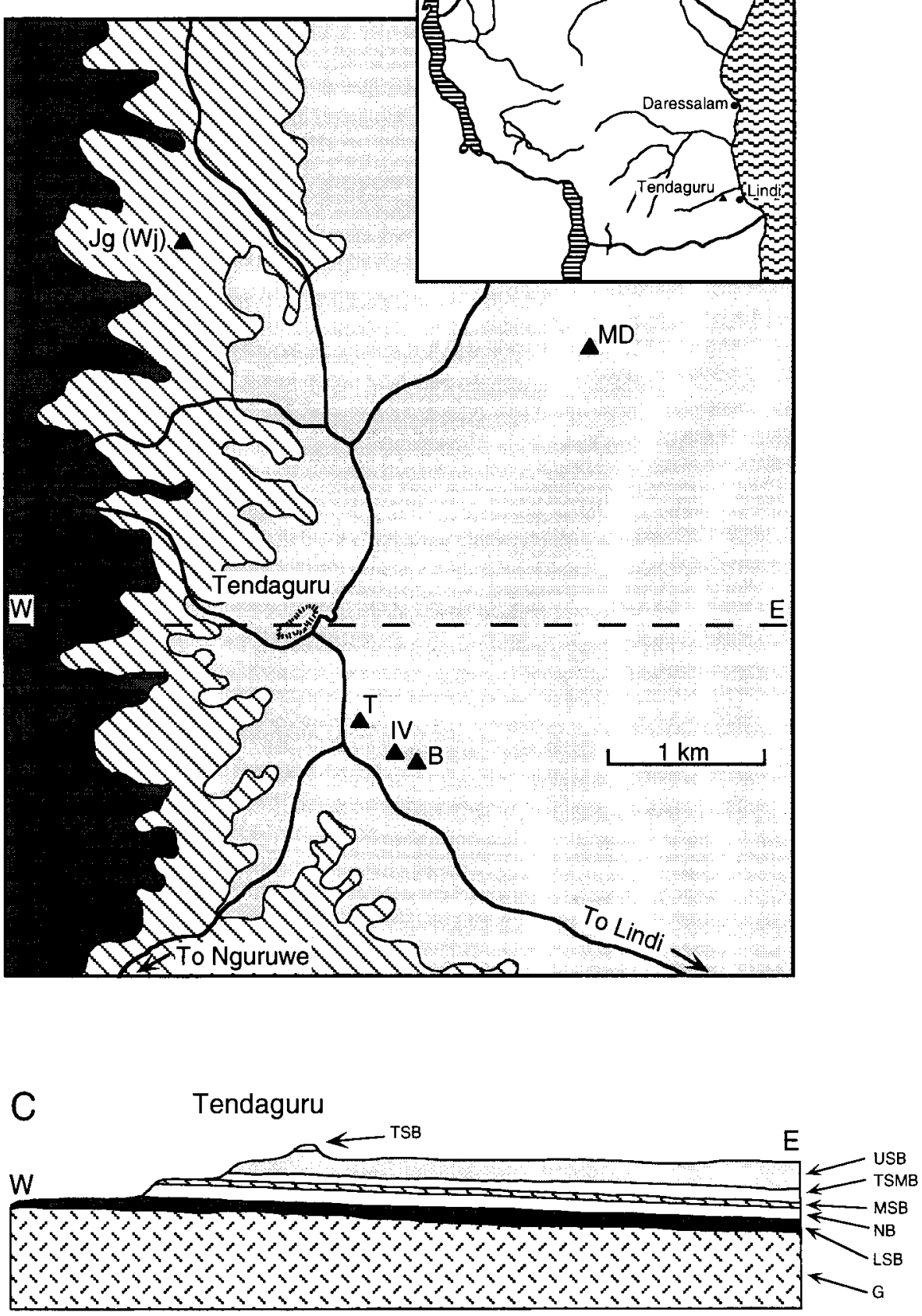

D

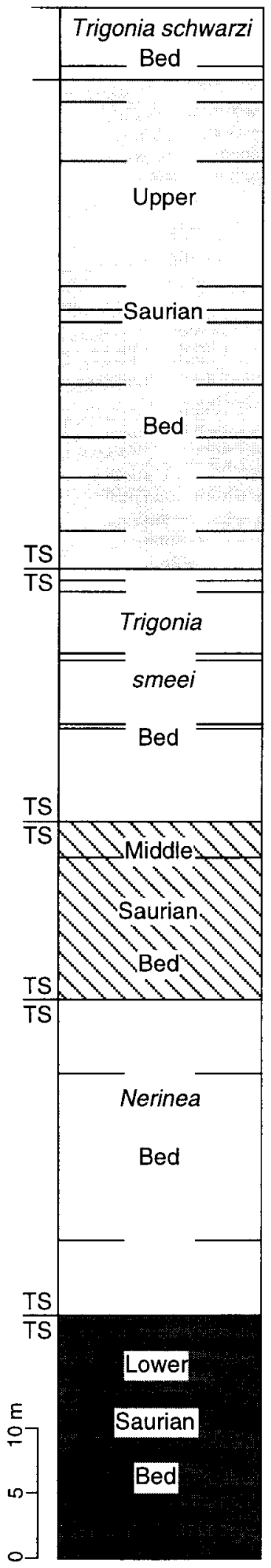

Fig. 1. Locality map for pterosaur remains found at Tendaguru. A, Africa, showing the location of Tanzania. B, Geology of the Tendaguru region indicating the relationships of the Saurian Beds. Inset map shows the location of Tendaguru within Tanzania. C, simplified stratigraphic cross-section through Tendaguru showing the topographic relationships of sediments that have yielded pterosaur remains. D, stratigraphic column showing, in diagrammatic form, the relationships of the main Upper Jurassic horizons at Tendaguru. Pterosaur localities: IV, B, Jg (Wj), MD and T. Abbreviations: G, Gneiss; LSB, Lower Saurian Bed; MSB, Middle Saurian Bed; NB, Nerinea Bed; TS Transitional sands; TSMB, Trigonia smeei Bed; TSB, Trigonia schwarzi Bed; USB, Upper Saurian Beds 
Site M2: This British expedition locality (Parkinson 1930: 145) was at Nguruwe, on the way from Tendaguru Hill to Namunda. However, nothing is known about the material from this site (Reck 1931: 325).

Other Tendaguru sites: Reck (1931: 325) mentioned that localities situated along the steep scarp slope extending from Nguruwe in the south to the ornithopod site at Kindope in the north had produced single pterosaur bones, but did not give the precise locations of these sites.

Reck noted (1931: 325) that with regard to the importance, quality and number of finds, that sites 69a and MD were the most important pterosaur localities. He also stated (1931: 325) that all levels of the Upper Saurian Beds yielded single bones, that a small number of bones were discovered, by chance, in the dinosaur trenches and that the latter was also true for the Middle Saurian Beds.

Taphonomy: Most of the pterosaur material recovered from the Tendaguru beds consists of isolated bones and according to Reck (1931) articulated remains were not found. However, accumulations of irregularly jumbled bones were discovered at Site $69 \mathrm{a}$, where they were thought to represent one individual, and at Site MD, where they were thought to represent a 'swarm' of pterosaurs (Reck 1931). The MfNHUB collections are dominated by postcranial remains, mainly from the forelimbs, though hind limb elements and some incomplete vertebrae are also present. A few teeth were recovered, but skull remains are extremely rare and seem to be confined to the specimen described here and a poorly preserved bone fragment of what appears to be the caudal end of a mandible (MB. unumbered). Generally, the limb bones are well preserved, and, in contrast to material from other Late Jurassic localities such as Solnhofen, they are usually uncrushed and undistorted.

\section{Systematic palaeontology}

Order Pterosauria Kaup, 1834

Suborder Pterodactyloidea Plieninger, 1901 Superfamily Dsungaripteroidea Young, 1964

Remarks: The Dsungaripteroidea is diagnosed by a series of cranial characters (see Unwin 1995, Unwin \& Lü 1997) and is currently composed of the families Germanodactylidae and Dsungaripteridae.

\section{Family Germanodactylidae}

Remarks: The Germanodactylidae currently contains two named genera: Germanodactylus Young, 1964 and Normannognathus Buffetaut, Lepage \& Lepage, 1998. It seems likely that Germanodactylidae is paraphyletic since some of the included taxa seem to be closer to the Dsungaripteridae than they are to other germanodactylids. However, this has yet to be formally demonstrated, so, for the present, we continue to use the family name Germanodactylidae.

\section{Tendaguripterus n. gen.}

Type and only known species: Tendaguripterus recki $\mathrm{n}$. gen. n. sp.

Derivation of name: Combination of Tendaguru, the type locality in Tanzania, and 'ptero' (Gr.) meaning wing.
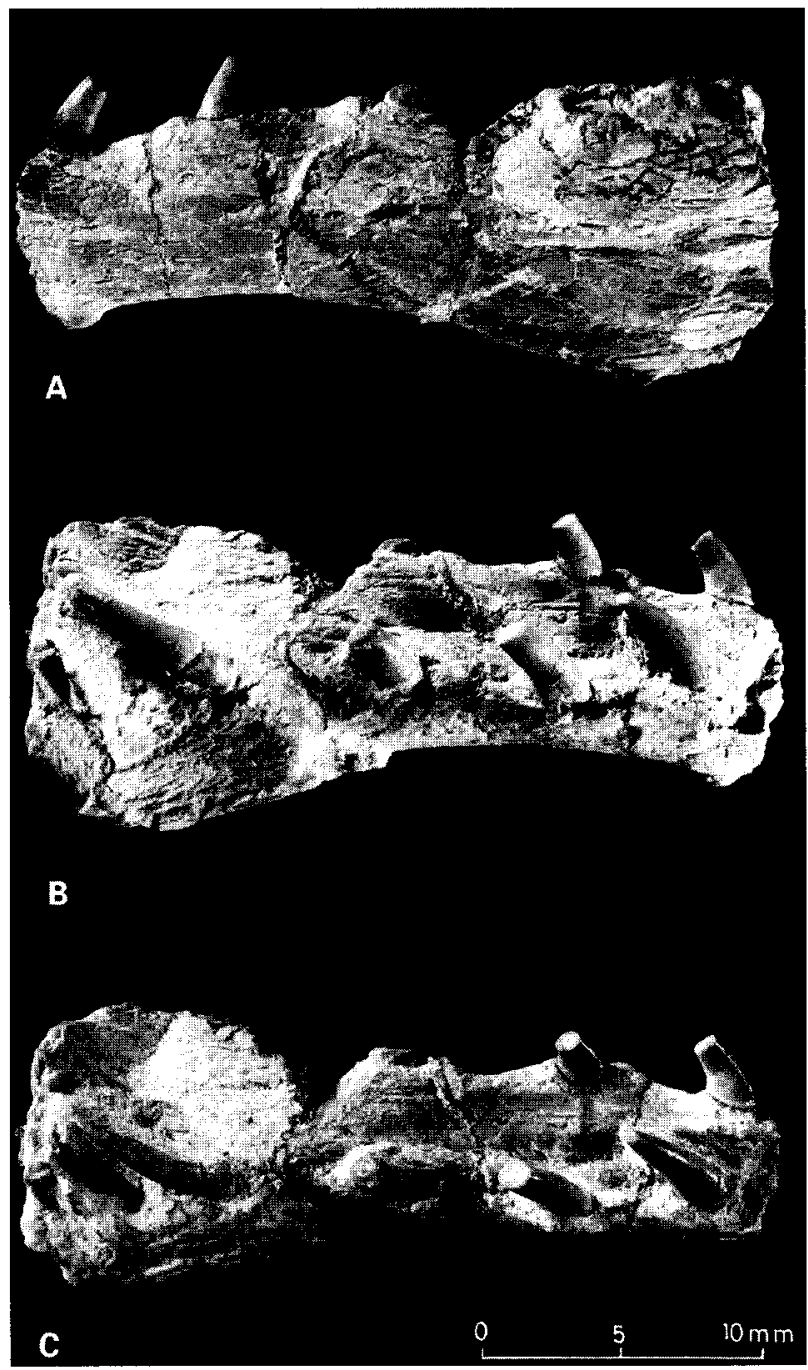

Fig. 2. Tendaguripterus recki n. gen. n. sp., holotype, MB.R.1290, section of the mandibular symphysis in (A) left lateral, (B) right lateral and (C) right dorsolateral view 
Diagnosis: Posterior section of mandibular symphysis with deeply concave ventral profile. Teeth in the posterior section of the mandibular symphysis inclined posterodorsally.

\section{Tendaguripterus recki n. gen. n. sp.}

Figs 2, 3

Derivation of name: The specific name honours Hans Reck, who was the first to describe pterosaurs from Tendaguru.

Holotype: An incomplete section of the mandibular symphysis, MB.R.1290.

Type locality: Excavation site Jg (Wj), Tendaguru, Tanzania (Fig. 1B).

Type horizon: Middle Saurian Beds, Tendaguru (the exact stratigraphic position is unknown).

Age: Upper Jurassic, Kimmeridgian-Tithonian.

Dimensions: See Table 1.
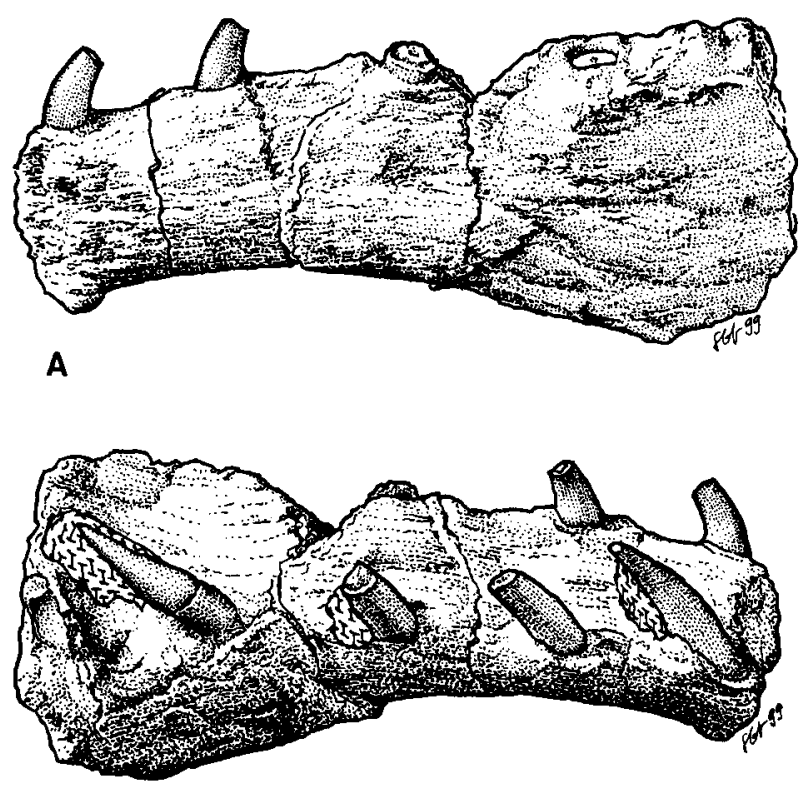

B

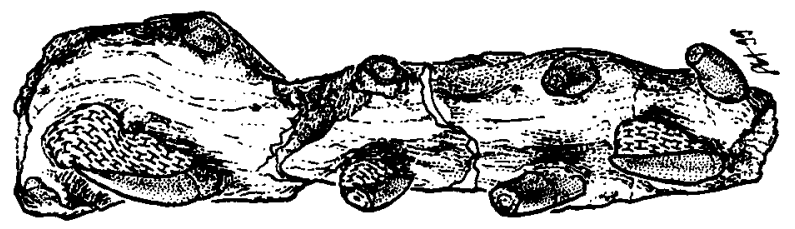

C

Fig. 3. Tendaguripterus recki n. gen. n. sp., holotype, MB.R.1290, section of the mandibular symphysis in (A) left lateral, (B) right dorsolateral and (C) palatal view. Scale bar $=5 \mathrm{~mm}$
Table 1

Dimensions of the holotype of Tendaguripterus recki n. gen. n. sp. (in $\mathrm{mm}$ )

Length 25.9

Maximum depth anterior end ${ }^{1}$ 6.0

Maximum depth posterior end ${ }^{1}$

Crown height fourth tooth, right side 9.9

6.0

Maximum basal tooth diameter ${ }^{2}$

Left side, tooth position

$\begin{array}{ll}\text { \#1 } & 11.6 \\ \text { \#2 } & 21.5 \\ \text { \# } 3 & 31.8 \\ \text { \# } 4 & 41.8 \\ \text { \# } 1 & 11.6 \\ \text { \#2 } & 21.7 \\ \text { \# } 3 & 31.8 \\ \text { \# } 4 & 41.75\end{array}$

Gap length between tooth positions ${ }^{3}$

Left side positions

$\begin{array}{ll}\# 1-2 & 3.6 \\ \# 2-3 & 4.4 \\ \# 3-4 & 4.5 \\ \# 1-2 & 3.2 \\ \# 2-3 & 4.0 \\ \# 3-4 & 4.15\end{array}$

Relative size of inter-tooth spacing ${ }^{4}$ Left side positions

$\begin{array}{ll}\# 1-2 & 2.25 \\ \# 2-3 & 2.94 \\ \# 3-4 & 2.5 \\ \# 1-2 & 2.0 \\ \# 2-3 & 2.35 \\ \# 3-4 & 2.37\end{array}$

Associated fauna: Site $\mathrm{Jg}(\mathrm{Wj})$ was one of the most productive Tendaguru localites yielding dinosaurs (Brachiosaurus, Elaphrosaurus, Dryosaurus and Kentrosaurus), a paramacellodid lizard (Broschinski, this volume) and mammals (Tendagurodon, Tendagurutherium and a haramiyid: Heinrich this volume, b).

Diagnosis: As for the genus.

\section{Description}

Preservation: The holotype material consists of a short section ( $25.9 \mathrm{~mm}$ long, as preserved) of the lower jaw symphysis. The anterior termination of the symphysis is missing. Comparison with related taxa such as Germanodactylus (Wellnhofer 1970) suggests that the missing anterior portion was at least $15 \mathrm{~mm}$ long. Judging by the apparent widening of the symphysis posteri-

\footnotetext{
${ }^{1}$ As preserved.

${ }^{2}$ Measured from anterior edge to posterior edge.

${ }^{3}$ Gap length is measured from the posterior edge of the leading tooth to the anterior edge of the following tooth.

${ }^{4}$ Ratio of gap length to basal diameter of leading tooth.
} 
orly it seems likely that this bone represents the posterior part of the symphysis immediately anterior to the point at which the left and right mandible diverged.

The fragment retains some of its three dimensional shape (as with many other pterosaur remains from Tendaguru), but it has been somewhat compressed, so that the palatal surface now slants down towards the right side and the jaw has a somewhat asymmetric outline in anterior or posterior aspect. The specimen is transected by three prominent fractures. The bone surfaces are reasonably well preserved, though eroded in places, and somewhat checked and fractured, a common feature of the relatively thin compacta of pterosaur bones.

The left dental margin bears four alveoli. The anterior two alveoli contain teeth lacking the tips of the crowns, but the teeth in the posterior two alveoli are broken off at their base, though in each case the tooth root remains. The right dental margin bears four complete alveoli and the remains of a fifth adjacent to the posterior break. Each of the first four alveoli contains a tooth: the first tooth lacks its tip, the second and third lack the distal half of the crown, but the fourth appears to be complete. Only a small portion of the medial margin of the fifth alveolus remains. It is not possible to determine the absolute position of these teeth with respect to the anterior or posterior end of the tooth row, hence the first preserved pair are nominally referred to here as pair one, the second as pair two and so on.

Anatomical description: The preserved remains indicate that this pterosaur had a relatively long symphysis that bore at least five pairs of dental alveoli. Anteriorly, the symphysis appears to have been relatively narrow, with a triangular cross-section that is somewhat deeper than broad. The depth of the symphysis at the anterior break corresponds to the total height of the complete tooth crown in the fourth right alveolus. Proceeding posteriorly there is a rapid increase in the depth of the symphysis and at the posterior break it is more than 1.5 times deeper than at the anterior break. This increase in depth is offset by widening of the symphysis, which begins just prior to the posterior break so that, when restored to its original shape, the cross-section at this point was a tall, narrow triangle of similar proportions to the profile of the anterior break.

The lateral surfaces of the symphysis were flat or slightly convex and met ventrally in a sharp edge. In lateral profile this edge has a distinctive concave outline reflecting the deepening of the symphysis posteriorly. The palatal surface of the symphysis is flat posteriorly, but, even taking compression and distortion into account, the anterior two thirds of this surface appears originally to have been somewhat depressed along the mid-line, forming a shallow groove whose sides sloped gently towards the dental margins of the symphysis. The presence of a midline groove confirms that the fossil represents the lower jaw since, in pterosaurs, the palatal surface of the symphysis often bears a midline groove, or is flat, whereas the palatal surface of the upper jaw has a midline ridge, or is flat.

A distinctive feature of the specimen is the expansion of the margins of each dental alveolus to form a low, rounded tumescence, from which the tooth erupts. This is most clearly exhibited on the left side of the symphysis (Figs 2A, C, $3 \mathrm{~A})$. In lateral view each alveolus is surrounded by a low boss of bone, while the dental margin between these bosses is gently concave: as a result, the dorsal profile of the symphysis has a distinctive scalloped appearance in lateral view.

The teeth are relatively slender (the one complete tooth has a crown/maximum base width ratio of 3.0), sharp-pointed and gently recurved, each exhibiting about the same degree of recurvature. The outer, labial surface is gently convex, while the inner, lingual surface is flatter. The labial and lingual surfaces meet in rounded anterior and posterior margins and carinae are not developed. Viewed from anterior the teeth appear to have stood approximately vertically in the jaw. However, when viewed from either the left or the right side, the teeth are clearly inclined toward the rear at a steep angle, hence, in this part of the jaw at least, the dentition was raked backward. This does not appear to be an artefact of preservation since the same type of orientation is evident in all reasonably well preserved teeth, irrespective of the distortion experienced by different parts of the jaw and the dental margins.

All preserved teeth appear to have been fully erupted and no replacement teeth are visible, though in the case of the third and fourth position on the right side of the jaw the point at which replacement teeth should appear (in the posteromedial margin of the alveolus) is obscured by sediment. The teeth show a small but consistent increase in basal diameter proceeding posteriorly (see Tab. 1), the fourth pair being $1.125 \times$ the size of the first pair. In addition, the 
teeth are relatively widely spaced: generally the inter-tooth spacing (measured from the posterior edge of the leading tooth to the anterior edge of the trailing tooth) is equivalent to at least twice the basal diameter of the leading tooth (Table 1). In addition, the posteriorward increase in tooth size is accompanied by a small but consistent increase in inter-tooth spacing (see Table 1).

The jaw fragment of Tendaguripterus recki n. gen. n. sp. is slightly smaller than the corresponding region of the lower jaw of Germanodactylus rhamphastinus (BSP AS I 745). Assuming that Tendaguripterus $\mathrm{n}$. gen. broadly resembled Germanodactylus (see below) this suggests an original skull length of somewhat less than $200 \mathrm{~mm}$ and a wingspan approaching $1000 \mathrm{~mm}$.

\section{Comparison}

Various features indicate that the find is pterosaurian: the smooth outer surface of the bone cortex, the thin bone walls of the jaw fragment, which is otherwise hollow, and the tooth morphology, relatively long, simple, sharp-pointed teeth lacking any serrations or carinae. The elongate mandibular symphysis shows that the specimen is pterodactyloid, since 'rhamphorhynchoids' either have a very short mandibular symphysis, or no symphysis at all.

Recent phylogenetic analyses have identified four major clades of pterodactyloids (Unwin \& Lü 1997): Ornithocheiroidea, Seeley, 1901, Ctenochasmatoidea Kuhn, 1967, Dsungaripteroidea Young, 1964, and Azhdarchoidea Unwin, 1992. The jaw described here lacks any diagnostic features of Ornithocheiroidea, Ctenochasmatoidea, or Azhdarchoidea (see Unwin 1995 and Unwin \& Lü 1997 for apomorphies of these taxa) but exhibits three characters only found in dsungaripteroids. These are as follows:

(1) A relatively deep lower jaw which, when viewed laterally, has a ventral margin that is distinctly concave toward the posterior end of the symphysis. This is evident in Dsungaripterus (Young, 1964, Fig. 2) and the dsungaripterid from Tatal, Mongolia (Bakhurina pers comm.), and is also visible, though less pronounced, in Germanodactylus cristatus (Wellnhofer 1970, Fig. 12) though not in G. rhamphastinus (Wellnhofer 1970, Fig. 13). By contrast, in other pterodactyloids, the ventral margin of the posterior symphysial region usually has a flat or a convex profile (Wellnhofer 1978, Figs 4, 5). In some taxa, such as Tropeognathus (Wellnhofer 1987) and Pteranodon (Eaton 1910), the ventral margin is also concave in this region, but this is associated with anterior deepening of the lower jaw, not posterior deepening, as in the case of dsungaripteroids. The ventral margin of the symphysis in Tendaguripterus $\mathrm{n}$. gen. has a lateral profile that is more concave than in any known dsungaripteroid, though this shape may have been overemphasised by postmortal deformation of the specimen.

(2) The margins of the dental alveoli are expanded to form low, rounded tumescences, from which the teeth erupt: thus, when viewed laterally, the dental margin has a scalloped profile. This feature is particularly well developed in Dsungaripterus (Young 1964, Fig. 2) and in the Tatal dsungaripterid, and is present, though only weakly developed, in Germanodactylus cristatus (BSP 1892 IV 1) and G. rhamphastinus (BSP AS I 745; BSP 1977 XIX 1). Inflated alveolar rims also occur in the Cretaceous pterosaur 'Pterodactylus' giganteus (Owen 1851, pl. 38, Figs 4-6) and 'Pterodactylus' sagittirostris (Owen 1874, pl. 2, Figs 1-8). In these cases, however, the expansion takes the form of a pedestal-like structure, rather than the rounded tumescence seen in dsungaripteroids. The dental alveoli of Tendaguripterus n. gen. are tumescent, as in dsungaripteroids, and more inflated than in Germanodactylus, but less so than in dsungaripterids.

(3) The largest teeth occur toward, or at, the posterior end of the tooth row. In Dsungaripterus (Young 1964, Fig. 2) and in the Tatal dsungaripterid (Wellnhofer 1991, p. 120) the smallest teeth occur at the anterior end of the tooth row and there is a steady increase in size posteriorly, the largest teeth occurring at the caudal end of the tooth row. In Germanodactylus the largest teeth occur in the middle, or just posterior to the middle of the tooth row (Wellnhofer 1970, Figs 12, 13). In other pterodactyloids the largest teeth usually occur at or toward the anterior end of the tooth row. The complete tooth row is not preserved in Tendaguripterus n. gen., but the steady increase in size, caudally, and the location of the largest preserved tooth adjacent to the posterior end of the symphysis corresponds to the situation in Germanodactylus where the largest tooth pair is usually located in the region of the posterior end of the symphysis. This suggests that the largest teeth of Tendaguripterus $\mathrm{n}$. gen. may also have been located in the posterior half of the tooth row, as in dsungaripteroids. 
Tendaguripterus n. gen. is closely comparable with dsungaripteroids in other respects, though these features may not be unique to this clade. The rapid broadening of the lower jaw at the posterior end of the symphysis is also evident in Dsungaripterus (Young 1964, Fig. 2) and the tooth morphology is almost identical to that of Germanodactylus rhamphastinus (Wellnhofer 1970, Fig. 13) though this tooth type occurs elsewhere in pterodactyloids. More importantly, in Tendaguripterus $\mathrm{n}$. gen. the teeth are separated by relatively large inter-tooth spaces (Table 1), that are always more than twice the size of the basal diameter of the leading tooth. Relatively large inter-tooth spacing also occurs in all known dsungaripteroids (Young, 1964, Fig. 2; Wellnhofer 1970, Figs 12, 13, Wellnhofer 1991, p. 120; Buffetaut et al. 1998, Fig. 1), though it seems to be somewhat less in the corresponding region of the dentition in these taxa. By contrast, in most Jurassic pterodactyloids, the inter-tooth spacing is usually little more than the basal diameter of the leading tooth (e.g. Pterodactylus), and sometimes even less than a single tooth diameter (e.g. Ctenochasma).

A number of features distinguish Tendaguripterus $\mathrm{n}$. gen. from other dsungaripteroids. The concavity of the ventral margin, when seen in lateral view, is deeper than in any other dsungaripteroid and the teeth are raked backwards. In Germanodactylus the teeth stand vertically or are procumbent in the anterior end of the dentition and the mandibles are only gently sigmoidal (Wellnhofer 1970). In Normannognathus the teeth also stood vertically (Buffetaut et al. 1998) and appear to have been more closely spaced than in Tendaguripterus $\mathrm{n}$. gen. In later dsungaripteroids (the Mongolian form, Dsungaripterus and Noripterus) the mandibular teeth are vertically oriented and the teeth are much more robust (shorter and more broadly based) than in Tendaguripterus n. gen. (cf. Wellnhofer 1991). In addition, these forms also have a relatively deep mandible.

\section{Relationships of Tendaguripterus n. gen. to other dsungaripteroids}

The interrelationships of dsungaripteroids are still only poorly understood. Dsungaripterus and the Tatal dsungaripterid share a number of derived features (such as the occurrence of the largest teeth at the caudal end of the tooth row) that unites them in a monophyletic taxon, the
Dsungaripteridae. The Jurassic dsungaripteroids including Germanodactylus, Normannognathus and Tendaguripterus $\mathrm{n}$. gen. lack apomorphies of the Dsungaripteridae, but their relationships to each other and to the Dsungaripteridae are difficult to resolve, principally because Normannognathus and Tendaguripterus n. gen. are so poorly known. Moreover, the distribution of characters, at least as determinable from preserved remains, exhibits some incongruency. Thus, as Buffetaut et al. (1998) have pointed out, Normannognathus has a cranial crest whose morphology is similar to that of Dsungaripterus and is clearly more derived than that of Germanodactylus, yet the dentition of Normannognathus is less derived than that of $G$. cristatus. The latter has toothless jaw tips and short, rather broad teeth whereas the dentition extends to the tip of the jaw in Normannognathus and the teeth are relatively slender - the typical condition for early pterodactyloids. A similar character incongruency occurs in Tendaguripterus n. gen. In this genus the rims of the dental alveoli show a marked expansion, but the teeth are relatively slender and sharp-pointed, like those of other early pterodactyloids. Germanodactylus cristatus, by contrast, has only very weakly developed alveolar rims, but a tooth morphology that is more like that of dsungaripterids than that of any of other Jurassic dsungaripteroid. It is doubtful that the interrelationships of Tendaguripterus n. gen., Germanodactylus and Normannognathus can be resolved until more complete material is available, thus, for the present, we assign these taxa to the Germanodactylidae, while noting that ultimately this taxon may be shown to be paraphyletic.

\section{A reassessment of other pterosaur taxa from Tendaguru}

Reck named four species of pterosaur from Tendaguru, a 'rhamphorhynchoid', 'Rhamphorhynchus tendagurensis', and three pterodactyloids, 'Pterodactylus arningi', 'Pterodactylus maximus' and 'Pterodactylus brancai'.

'Rhamphorhynchus tendagurensis' (MB.R.2845) was based on the associated, and well preserved, but incomplete distal end of a right radius and ulna (Reck 1931, Fig. 1). This material has a number of characters that are found in 'rhamphorhynchoids', but are absent in pterodactyloids:

(1) The distal end of the radius is of similar height (measured dorsoventrally) to the ulna. 
This is typical of 'rhamphorhynchoids' (Wellnhofer 1978, Fig. 11), but not pterodactyloids, where the distal end of the ulna tends to be more robust and a little deeper to much deeper than the radius (Wellnhofer 1978, Fig. 11).

(2) The articular surface on the distal end of the ulna is of relatively simple construction, as in 'rhamphorhynchoids' (e.g. Dorygnathus, MB 1977.21), and consists of a single, large, rollerlike structure. In pterodactyloids, the articular surface is more complex with a large, convex, dorsal facet, a tuberculum at mid-height and a shallow fovea ventral to the tuberculum (e.g. Wellnhofer 1985, Figs 9, 25). These features are clearly absent in MB.R.2845 (though present in some other ulnae from Tendaguru - see below) suggesting that these remains are not pterodactyloid.

(3) Immediately adjacent to its distal termination, the anterodorsal margin of the ulna shaft bears a large, well-marked tendon groove, bounded dorsally by a prominent 'lip-like' process. This feature is evident in 'rhamphorhynchoids' (e.g. Rhamphorhynchus: BMNH R42380 and Eudimorphodon ranzii, Wild 1978, Fig. 17) but is absent, or only weakly developed in pterodactyloids.

In other respects, such as their general morphology and relative dimensions, these bones also compare well with those of 'rhamphorhynchoids' such as Rhamphorhynchus (Wellnhofer 1970), Dorygnathus (MB 1977.21) and Eudimorphodon (Wild 1978, Fig. 17). Reck identified these remains as a new species of Rhamphorhynchus, but, comparison with the corresponding region in well preserved specimens of this pterosaur (MGUH VP 2304; BMNH $\mathrm{R} 42380$ ) reveals at least one clear difference. In Rhamphorhynchus, the distal articular surface of the ulna is divided into two facets, the lower of which is saddle-shaped. This is quite unlike MB.R.2845 which has a single, continuous facet, the ventral half of which forms a tapering rollerlike structure. Further work on pterosaur phylogeny might ultimately allow MB.R.2845 to be assigned to a particular clade within 'Rhamphorhynchoidea', but, until this can be established the specimen is referred to 'Rhamphorhynchoidea' incertae sedis.

'Pterodactylus maximus' is based on a large right ulna (MB.R.2844), $198 \mathrm{~mm}$ long. The bone is uncrushed, but each articular end is somewhat eroded. Reck diagnosed this new species on the basis of its large size compared to other Tendaguru remains, but size is not a diagnostic charac- teristic in pterosaurs. The distal end of the ulna is expanded and bears a well developed articular surface consisting of a large dorsal facet, a small tubercle (now badly eroded) at mid-height and a small fovea located immediately below the tubercle. These features show that the specimen represents a pterodactyloid. Pterodactyloids have two distinct ulna morphologies. In ornithocheiroids, the dorsal facet occupies only one half, or less, of the entire distal articular surface (Wellnhofer 1985, Fig. 9). By contrast, in dsungaripteroids (e.g. Young 1964, Fig. 4a), azhdarchoids (e.g. Nessov 1997, pl. 15, Fig. 16), and possibly ctenochasmatoids, the dorsal facet occupies considerably more than half the articular surface and the tuberculum and fovea are relatively small structures. The Tendaguru specimen MB.R.2844, with its prominent dorsal facet clearly belongs to the second type, but it does not bear any features that might help to further resolve its taxonomic identity. Moreover, it does not have any characters that distinguish it from other pterodactyloids (other than ornithocheiroids) thus we consider 'Pterodactylus maximum' to be a nomen dubium.

'Pterodactylus brancai' was erected on the basis of a left tibiotarsus (MB.R.2842) and a left wing-phalanx one (MB.R.2848), though the association of these remains is unclear: they were found at the same locality, but it is not known if they came from the same individual. The tibiotarsus (Reck 1931, Galton 1980) is almost certainly pterodactyloid, since the fibula is relatively short, and fuses with the shaft of the tibia just beyond the mid length point of the latter - a diagnostic feature of this clade. This specimen also compares closely in other respects to the tibiotarsi of pterodactyloids and, in particular, shows a strong resemblance to the corresponding element in the dsungaripteroids Germanodactylus (BSP 1892 IV 1, BSP AS I 745, NMING 15005), Dsungaripterus (Young 1964, Fig. 7), Noripterus (Young 1973, Fig. 5) and the Tatal dsungaripterid (Bakhurina 1982, Fig. 1). The main distinction between the tibiotarsi of these taxa and that of 'Pterodactylus brancai' is size, but otherwise they are remarkably similar. The Tendaguru specimen does not exhibit any characters that might enable it to be assigned to any particular genus of dsungaripteroid, nor does it have any features that distinguish it from these taxa, thus, for the present, we identify it as Dsungaripteroidea gen. et sp. indet.

The wing phalanx one assigned to 'Pterodactylus brancai' (MB.R.2848) is complete, except 
that the proximal tip of the proximal extensor process is missing (Reck 1931, Fig. 4). The phalanx has a very distinctive and marked forward curvature, an important character of dsungaripteroid pterosaurs (Unwin et al. 1996), and has two further characters of this taxon: the bone walls appear to have been relatively thick, with only a narrow lumen (Unwin 1988, Bennett 1989), and the distal articular end is markedly expanded (Unwin et al. 1996). Assignment to Dsungaripteroidea is clearly warranted. However, within this group the morphology of the wing phalanx one shows little variation, other than size, and the Tendaguru specimen cannot be safely assigned to any of the known genera, nor does it exhibit any characters that enable it to be distinguished from these taxa. For the present, therefore, we assign it to Dsungaripteroidea gen. et sp. indet.

In conclusion, since neither of the specimens upon which 'Pterodactylus brancai' were based exhibits any features by which this taxon may be diagnosed we consider this name, and the synonym 'Dsungaripterus brancai', to be a nomen dubium. However, as Galton (1980) first noted, the holotype material shows some similarity to the corresponding elements of Dsungaripterus, and this is discussed further below.

'Pterodactylus arningi' was erected on the basis of a single, almost complete, left wing phalanx one (MB.R.2843). The anterior tip of the extensor process is missing and the posterior margin of the proximal end is badly eroded (Reck 1931, Fig. 5). The phalanx is almost as long as MB.R.2848, but, as Reck (1931) noted, the shaft has a much more slender build. In addition, the bone is not reflexed forwards and the bone walls appear to be relatively much thinner than in MB.R.2848. This specimen cannot therefore be assigned to the Dsungaripteroidea. However, it is so singularly bereft of any distinctive features that, for the present, it cannot be assigned to any taxon other than Pterosauria indet., and 'Pterodactylus arningi' must be considered a nomen dubium.

In conclusion, none of the previously proposed Tendaguru taxa appear to be valid, but this is not surprising since single, isolated, postcranial elements rarely bear features sufficient upon which to base the diagnosis of new genera or species. A corollary of this conclusion is that neither Pterodactylus nor Rhamphorhynchus are present in the Tendaguru deposits, confirming earlier doubts (Wellnhofer 1978) regarding the taxonomic assignments made by Reck (1931).

\section{Discussion}

The evolutionary history of dsungaripteroid pterosaurs: Until recently, little was known of the fossil record of dsungaripteroids and they were represented only by Germanodactylus from the Upper Jurassic of Bavaria and Dsungaripterus and Noripterus from the Early Cretaceous of China (Young 1964, 1973, Wellnhofer 1970, 1978). In the last two decades a series of important new finds have been made (Table 2) and these have considerably expanded our knowledge of this group. The most important of these discoveries includes material from Mongolia (Bakhurina 1982, 1986), the recognition of dsungaripteroids in the Tendaguru pterosaur assemblage (Galton 1980), a new genus from France (Buffetaut et al. 1998) and the recognition of dsungaripteroids in South America (Galton 1980, Unwin 1996, Martill and Frey pers comm. 1999).

This compilation of data on the fossil record of dsungaripteroids shows, however, that the known stratigraphic range of the clade, Upper Jurassic (Kimmeridgian) through to the mid Lower Cretaceous (the exact age depends on the dating of the Wuerho pterosaurs which is uncertain [Dong 1992]) has hardly changed since the first recognition of the group by Young in 1964 . Interestingly, dsungaripteroids have not been found in any of the main late Early or early Late Cretaceous pterosaur localities of Europe (Cambridge Greensand and Lower Chalk of England), Africa (Cenomanian of Morocco), Asia (Upper Cretaceous of Uzbekistan) or the Americas (Santana and Crato Formations of Brazil, Niobrara Chalk of Kansas). This suggests that dsungaripteroids may have become extinct sometime in the late Early Cretaceous.

In the Late Jurassic dsungaripteroids appear to have been rather diverse and widely distributed, occurring in Laurasia (Europe and ?North America) and in Gondwana (Africa and ?South America). This suggests that they were already well established by this time and that the group originated somewhat earlier in the Jurassic. Herbstosaurus (Casamiquela 1975), which is late Middle Jurassic (Callovian), might provide direct evidence for this, but its assignment to the Dsungaripteroidea has yet to be established (Unwin 1996).

The Tendaguru pterosaur assemblage: The excavations at Tendaguru yielded more than 200 remains of pterosaurs. Many of these consist of incomplete bone shafts lacking articular ends and can only be identified as Pterosauria incertae sedis. A small proportion of the re- 
mains are more complete and, in many cases, can be identified with a little more precision. Most of these bones appear to be pterodactyloid and often compare well with corresponding elements of dsungaripteroids (e.g. MB.R.2842 and 2848 , discussed above). These remains correspond broadly in size to the holotype of Tendaguripterus recki n. gen. n. sp. and probably belong to this taxon, but, unless more complete material is found, this cannot be demonstrated with certainty. A few of the identifiable remains appear to represent 'rhamphorhynchoids' (e.g. MB.R.2845), but further study is needed to establish their identity more precisely.

Thus, at a general level, the taxonomic composition of the Tendaguru pterosaur assemblage resembles that from other Upper Jurassic sites, in that both 'rhamphorhynchoids' and pterodactyloids are present, and most of the individuals appear to have been small to medium sized, the largest reaching an estimated $2-2.5 \mathrm{~m}$ in wingspan. However, when considered in more detail, the composition of the Tendaguru assemblage exhibits some distinct differences from that of other Upper Jurassic pterosaur localities. 'Rhamphorhynchoids' are exceptionally rare in the Tendaguru collections, which is in sharp contrast to the Solnhofen Limestone, Kimmeridge Clay and Karatau assemblages, wherein 'rhamphorhynchoids' represent between 50 and 100 per cent of the total number of identifiable individuals (e.g. Wellnhofer 1991). Similarly, the apparent preponderance of dsungaripteroids at Tendaguru also contrasts with the situation in the other Jurassic assemblages mentioned above, wherein dsungaripteroids are rare or absent (see Wellnhofer 1991). In this respect, the taxonomic composition of Tendaguru is most closely comparable with the Early Cretaceous dsungaripteroid dominated pterosaur assemblages of Tatal, Mongolia (Bakhurina 1986) and Xinjiang, China (Dong 1992). The contrasts and similarities among these various Upper Jurassic and Lower Cretaceous localities are so marked that they cannot be entirely attributed to taphonomic biasing and may perhaps reflect ecological or palaeobiogeographical differences between these pterosaur assemblages.

\section{Acknowledgements}

We are very grateful to H.-H. Krueger (MfN) for his assistance with the preparation of the specimen and to W. Harre, E. Siebert, V. Heinrich and T. Bergmann for their help with preparation of the figures. We thank N. Bakhurina, Bristol,
P. Wellnhofer, Munich, E. Frey, Karlsruhe, Z. Dong and J. Lü, Beijing, and S. Etches, Kimmeridge, for giving access to and assistance with material in their care. We are especially grateful to N. Bakhurina, M. Benton, D. Martill and P. Wellnhofer for their valuable comments on earlier versions of the MS.

\section{References}

Aitken, W. G. 1961. Geology and Palaeontology of the Jurassic and Cretaceous of Southern Tanganyika. - Bulletin of the Geological Survey of Tanganyika 31: $1-144$.

Bakhurina, N. N. 1982. [A pterodactyl from the Lower Cretaceous of Mongolia]. - Palaeontologicheskii Zhurnal (1982) 4: 104-108 [In Russian].

- 1986. [Flying reptiles]. - Priroda (1986) 7: 27-36 [In Russian].

Bakhurina, N. N. \& Unwin, D. M. 1995. A survey of pterosaurs from the Jurassic and Cretaceous of the former Soviet Union and Mongolia. - Historical Biology 10: $197-245$

Bennett, S. C. 1989. A pteranodontid pterosaur from the Early Cretaceous of Peru, with comments on the relationships of Cretaceous pterosaurs. - Journal of Paleontology 63: $669-676$.

- 1994. Taxonomy and systematics of the Late Cretaceous pterosaur Pteranodon (Pterosauria, Pterodactyloidea). Occasional Papers of the Natural History Museum. The University of Kansas, Lawrence, Kansas 169: 1-70.

Benton, M. J., Cook, E., Grigorescu, D., Popa, E. \& Tallodi, E. 1997. Dinosaurs and other tetrapods in an Early Cretaceous bauxite-filled fissure, northwestern Romania. Palaeogeography, Palaeoclimatology and Palaeoecology 130: $275-292$.

Bonaparte, J. F. 1978. El Mesozoico de America del Sur y sus Tetrapodos. - Opera Lilloana 26. Tucuman, Argentina.

Bonaparte, J. F. \& Sanchez, T. M. 1975. Restos de un pterosaurio, Puntanipterus globosus de la Formacion La Cruz, Provincia de San Luis, Argentina. - Acta primero Congreso Argentino de Paleontologia y Bioestratigrafia 2: $105-113$.

Broschinski, A. 1999. Ein Lacertilier (Scincomorpha, Paramacellodidae) aus dem Oberen Jura von Tendaguru/Tansania. - Mitteilungen aus dem Museum für Naturkunde Berlin, Geowissenschaftliche Reihe 2: 155-158.

Buffetaut, E., Lepage, J.-J. \& Lepage, G. 1998. A new pterodactyloid pterosaur from the Kimmeridgian of the Cap de la Hève (Normandy, France). - Geological Magazine 135: 719-722.

Casamiquela, R. M. 1975. Herbstosaurus pigmaeus (Coeluria, Compsognathidae) n. gen. n. sp. del Jurasico medio del Neuquén (Patagonia septentrional). Uno de los más pequenos dinosaurios conocidos. - Acta primero Congresso Argentino Paleontologia et Bioestratigrafia 2: 87-102.

Casamiquela, R. M. \& Diaz, G. C. 1978. La presencia de Pterodaustro Bonaparte (Pterodactyloidea), del Neojurassico (?) de la Argentina, en Los Andes del norte de Chile. - Actas del Segundo Congresso Argentino de Paleontologia y Bioestratigrafia y Primer congresso Latinamericano de Paleontologia 1: 201-209.

Dong, Z. 1992. Dinosaurian faunas of China. 188 pp. China Ocean Press.

- 1993. The field activities of the Sino-Canadian Dinosaur Project in China, 1987-1990. - Canadian Journal of Earth Science 30: 1997-2001.

Eaton, G. F. 1910. Osteology of Pteranodon. - Memoirs of the Connecticut Academy of Arts and Sciences 2: 1-38.

Galton, P. M. 1980. Avian-like tibiotarsi of pterodactyloids (Reptilia: Pterosauria) from the Upper Jurassic of East Africa. - Paläontologische Zeitschrift 54: 331-342. 
Harris, J. D. \& Carpenter, K. 1996. A large pterodactyloid from the Morrison Formation (Late Jurassic) of Garden Park, Colorado. - Neues Jahrbuch für Geologie und Palaeontologie Monatsheft 1996 (8): 473-484.

Heinrich, W.-D. 1999a. The taphonomy of dinosaurs from the Upper Jurassic of Tendaguru, Tanzania (East Africa), based on field sketches of the German Tendaguru expedition (1909-1913). - Mitteilungen aus dem Museum für Naturkunde Berlin, Geowissenschaftliche Reihe 2: 25-61.

- 1999b. First haramiyid (Mammalia, Allotheria) from the Mesozoic of Gondwana. - Mitteilungen aus dem Museum für Naturkunde Berlin, Geowissenschaftliche Reihe 2: 159-170.

Janensch, W. 1914a. Die Gliederung der Tendaguru-Schichten im Tendaguru-Gebiet und die Entstehung der SaurierLagerstätten. - Archiv für Biontologie 3 (3): 227-261.

- 1914b. Übersicht über die Wirbeltierfauna der Tendaguru-Schichten, nebst einer kurzen Charakterisierung der neu aufgestellten Arten von Sauropoden. - Archiv für Biontologie 3 (1): 81-110.

- 1925. Die Grabungsstellen der Tendaguru-Gegend. - Palaeontographica, Supplement VII, 1 Reihe, Teil 1, Lieferung 1: XVII-XIX.

Jensen, J. A. \& Ostrom, J. H. 1977. A second Jurassic pterosaur from North America. - Journal of Paleontology 51: $867-870$.

Kaup, J. 1834. Versuch einer Einteilung der Säugetiere. p. 315. Isis von Oken, Jena.

Kellner, A. W. A. \& Mader, B. J. 1996. First report of Pterosauria (Pterodactyloidea, Azhdarchidae) from Cretaceous rocks of Morocco. - Journal of Vertebrate Paleontology 16 supp. to nb. 3: $45 \mathrm{~A}$.

Kuhn, O. 1967. Die Fossile Wirbeltierklasse Pterosauria. 52 pp., Verlag Oeben, München-Krailing.

Mader, B. J. \& Kellner, A. W. A. 1997. First occurrence of Anhangueridae (Pterosauria, Pterodactyloidea) in Africa. - Journal of Vertebrate Paleontology 17 supp. to nb. 3: $62 \mathrm{~A}$.

- 1999. A new anhanguerid pterosaur from the Cretaceous of Morocco. - Boletim do Museu Nacional Geologia 45: $1-11$.

Monteillet, J., Lappartient, J. R. \& Taquet, P. 1982. Un ptérosaurien géant dans le Crétacé supérieur de Paki (Senegal). - Comptes rendus de l'Académie des Sciences de Paris (3) 295: 167-172.

Nessov, L. A. 1997. Cretaceous nonmarine vertebrates of Northern Eurasia (Golovneva and Averianov, ed.). 218 pp. University of Sankt-Petersburg, Institute of Earths Crust.

Niu, S. W. 1987. Late Mesozoic strata of the Jinquan Basin in Gansu. - Journal of Statigraphy 11: 1-22.

Owen, R. 1851. Monograph on the fossil Reptilia of the Cretaceous Formations. Part I. Chelonia, Lacertilia, etc. The Palaeontographical Society: 80-104.

- 1874. A Monograph on the Fossil Reptilia of the Mesozoic Formations. Monograph on the Order Pterosauria. The Palaeontographical Society: 1-14.

Parkinson, J., 1930. The dinosaur in East Africa. An account of the giant reptile beds of Tendaguru, Tanganyika Territory. 192 pp. H. F. \& G. Witherby, London.

Plieninger, F. 1901. Beiträge zur Kenntniss der Flugsaurier. Palaeontographica 48: $65-88$.

Reck, H. 1931. Die deutschostafrikanischen Flugsaurier. Centralblatt für Mineralogie, Geologie und Paläontologie 1931: $321-336$
Russell, D., Béland, P. \& McIntosh, J. S. 1980: Paleoecology of the dinosaurs of Tendaguru (Tanzania). - Memoires Sociéte Geologique de France 139: 169-175.

Seeley, H. G. 1901. Dragons of the air. An account of extinct flying reptiles. $238 \mathrm{pp}$. Methuen.

Sereno, P. C., Beck, A. L., Dutheil, D. B., Gado, B., Larsson, H. C. E., Lyon, G. H., Marcot, J. D., Rauhut, O. W. M. Sadleir, R. W., Sidor, C. A., Varricchio, D. D., Wilson, G. P. and Wilson, J. A. 1998. A long-snouted predatory dinosaur from Africa and the evolution of the spinosaurids. Science 282: 1298-1302.

Sun, A., Li, J., Ye, X., Dong, Z. and Hou, L. 1992. The Chinese fossil reptiles and their kins. 260 pp. Science Press, Beijing.

Swinton, W. E. 1948. A Cretaceous pterosaur from the Belgian Congo. - Bulletin de la Société Belge de Géologie, de Paléontologie et d'Hydrologie 77: 234-238.

Unwin, D. M. 1988. A new pterosaur from the Kimmeridge Clay of Kimmeridge, Dorset. - Proceedings of the Dorset Natural History and Archaeological Society 109: $150-153$.

- 1992. The phylogeny of the Pterosauria. - Journal of Vertebrate Paleontology 12 (Suppl. to 3): 57A.

- 1995. Preliminary results of a phylogenetic analysis of the Pterosauria (Diapsida: Archosauria). In Sun, A. \& Y. Wang (eds). Sixth Symposium on Mesozoic Terrestrial Ecosystems and Biota: 69-72. China Ocean Press, Beijing.

- 1996. The fossil record of Middle Jurassic pterosaurs. In Morales, M. (ed.). The Continental Jurassic. - Museum of Northern Arizona Bulletin 60: 291-304.

Unwin, D. M. \& Lü, J. 1997. On Zhejiangopterus and the relationships of pterodactyloid pterosaurs. - Historical Biology 12: 199-210.

Unwin, D. M., Manabe, M., Shimizu, K. \& Hasegawa, Y. 1996. First record of pterosaurs from the Early Cretaceous Tetori Group: a wing-phalanx from the Amagodani Formation in Shokawa, Gifu Prefecture, Japan. - Bulletin of the National Science Museum, Tokyo, Series C, Geology and Paleontology 22: 37-46.

Wellnhofer, P. 1970. Die Pterodactyloidea (Pterosauria) der Oberjura-Plattenkalke Süddeutschlands. - Abhandlungen der Bayerischen Akademie der Wissenschaften zu München, Mathematisch-Naturwisenschaftliche Klasse 141: $1-133$.

- 1978. Handbuch der Paläoherpetologie. Teil 19, Pterosauria. $82 \mathrm{pp}$. Gustav Fischer Verlag, Stuttgart.

- 1985. Neue Pterosaurier aus der Santana-Formation (Apt.) der Chapada do Araripe, Brasilien. - Palaeontographica A 187: 105-182.

- 1987. New crested pterosaurs from the Lower Cretaceous of Brazil. - Mitteilungen der Bayerischen Staatssammlung für Paläontologie und historische Geologie 27: $175-186$.

- 1991. The illustrated encyclopedia of pterosaurs. $192 \mathrm{pp}$ Salamander Books, London.

Wild, R. 1978. Die Flugsaurier (Reptilia, Pterosauria) aus der Oberen Trias von Cene bei Bergamo, Italien. - Bollettino della Società Paleontologica Italiana 17: 176-256.

Young, C. C. 1964. On a new pterosaurian from Sinkiang, China. - Vertebrata Palasiatica 8: 221-255.

- 1973. [Wuerho pterosaurs]. - Special Publication of the Institute of Vertebrate Palaeontology and Palaeoanthropology, Academica Sinica 11: $18-34$ [In Chinese]. 


\begin{tabular}{|c|c|c|c|c|c|}
\hline Taxon & Horizon and locality & Age & Material & Author & Notes \\
\hline \multicolumn{6}{|l|}{ Dsungaripteroidea } \\
\hline \multicolumn{6}{|l|}{ Germanodactylidae } \\
\hline $\begin{array}{l}\text { Germanodactylus } \\
\text { rhamphastinus }\end{array}$ & $\begin{array}{l}\text { Solnhofen Plattenkalk, } \\
\text { Mornsheim Schichten, } \\
\text { Bavaria, Germany }\end{array}$ & Late Jurassic & $\begin{array}{l}\text { Five skeletons of varying } \\
\text { completeness }\end{array}$ & $\begin{array}{l}\text { Wellnhofer } 1970 \\
\text { (and refs therein). }\end{array}$ & \\
\hline Germanodactylus cristatus & $\begin{array}{l}\text { Solnhofen Plattenkalk, } \\
\text { Bavaria, Germany }\end{array}$ & Late Jurassic & $\begin{array}{l}\text { A single almost complete } \\
\text { skeleton }\end{array}$ & $\begin{array}{l}\text { Wellnhofer } 1970 \\
\text { (and refs therein) }\end{array}$ & \\
\hline Germanodactylus sp. & $\begin{array}{l}\text { Kimmeridge Clay, Kimmer- } \\
\text { idge Bay, Dorset, England }\end{array}$ & Late Jurassic & $\begin{array}{l}\text { Seven bone remains, } \\
\text { some incomplete }\end{array}$ & Unwin 1988 & \\
\hline $\begin{array}{l}\text { Tendaguripterus recki n. gen. } \\
\text { n. sp. }\end{array}$ & Tendaguru, Tanzania & Late Jurassic & Incomplete lower jaw & this paper & $\begin{array}{l}\text { Other dsungaripteroid remains } \\
\text { from Tendaguru may belong } \\
\text { to this taxon }\end{array}$ \\
\hline Normannognathus wellnhoferi & $\begin{array}{l}\text { Octeville, Seine-Maritime, } \\
\text { Haute-Normandie, France }\end{array}$ & Late Jurassic & $\begin{array}{l}\text { associated anterior portions } \\
\text { of upper and lower jaws }\end{array}$ & Buffetaut et al. 1998 & \\
\hline \multicolumn{6}{|l|}{ Dsungaripteridae } \\
\hline 'Dsungaripterus parvus' & $\begin{array}{l}\text { Tsagan-Tsab Svita, Tatal, } \\
\text { Western Mongolia }\end{array}$ & Early Cretaceous & $\begin{array}{l}\text { Extensive series of cranial } \\
\text { and postcranial remains }\end{array}$ & $\begin{array}{l}\text { Bakhurina 1982, 1986, } \\
\text { Bakhurina \& Unwin } 1995\end{array}$ & $\begin{array}{l}\text { 'Phobetor' Bakhurina, } 1986 \\
\text { is preoccupied }\end{array}$ \\
\hline Noripterus complicidens & $\begin{array}{l}\text { Tugulu Group, Wuerho, } \\
\text { Xinjiang China. }\end{array}$ & Early Cretaceous & $\begin{array}{l}\text { Jaws plus a complete left } \\
\text { fore and hind limb }\end{array}$ & Young 1973, Sun et al. 1992 & \\
\hline Dsungaripterus weii & $\begin{array}{l}\text { Tugulu Group, Wuerho, } \\
\text { Xinjiang China. }\end{array}$ & Early Cretaceous & $\begin{array}{l}\text { Skulls and an extensive } \\
\text { series of postcranial remains }\end{array}$ & Young 1964, 1973 & \\
\hline Noripterus sp. & $\begin{array}{l}\text { Xinminbao Formation, } \\
\text { Xinminbao, China }\end{array}$ & Early Cretaceous & $\begin{array}{l}\text { Remains of a small } \\
\text { pterosaur }\end{array}$ & Niu 1987 & \\
\hline $\begin{array}{l}\text { New genus and species } \\
\text { of dsungaripterid }\end{array}$ & $\begin{array}{l}\text { Quebrada de la Carreta, } \\
\text { Cordillera de Domeyko, } \\
\text { Province of Antofagasta, } \\
\text { Chile. }\end{array}$ & Early Cretaceous & skull fragments & $\begin{array}{l}\text { Martill and Frey } \\
\text { pers comm. } 1999\end{array}$ & $\begin{array}{l}\text { Previously identified } \\
\text { as Pterodaustro by } \\
\text { Casamiquela \& Diaz } 1978\end{array}$ \\
\hline $\begin{array}{l}\text { Dsungaripteridae gen. } \\
\text { et sp. indet. }\end{array}$ & $\begin{array}{l}\text { Ookurodani Formation, } \\
\text { Shoukawa Village, } \\
\text { Gifu Prefecture Japan }\end{array}$ & Early Cretaceous & wing phalanx & Unwin et al. 1996 & \\
\hline $\begin{array}{l}\text { Dsungaripteridae gen. } \\
\text { et sp. indet. }\end{array}$ & $\begin{array}{l}\text { Pingfengshan locality, } \\
\text { Wucaiwan region, } \\
\text { Junggar Basin, Xinjiang, } \\
\text { China }\end{array}$ & $\begin{array}{l}\text { Late Jurassic-Early } \\
\text { Cretaceous }\end{array}$ & $\begin{array}{l}\text { numerous fragmentary } \\
\text { remains }\end{array}$ & Dong 1993 & \\
\hline
\end{tabular}




\begin{tabular}{|c|c|c|c|c|c|}
\hline Taxon & Horizon and locality & Age & Material & Author & Notes \\
\hline $\begin{array}{l}\text { Dsungaripteridae gen. } \\
\text { et sp. indet. }\end{array}$ & $\begin{array}{l}\text { Qingshan Formation, } \\
\text { Laiyang, Shandong } \\
\text { Province, China }\end{array}$ & Early Cretaceous & isolated bones & Young 1964 & \\
\hline $\begin{array}{l}\text { Dsungaripteridae gen. } \\
\text { et sp. indet. }\end{array}$ & $\begin{array}{l}\text { Mengyin Formation, } \\
\text { Mengyin, China }\end{array}$ & $\begin{array}{l}\text { Late Jurassic-Early } \\
\text { Cretaceous }\end{array}$ & wing phalanx & Young 1964 & \\
\hline
\end{tabular}

\section{Putative dsungaripteroids}

Kepodactylus insperatus

Puntanipterus globosus

Herbstosaurus pigmaeus

Dsungaripterus sp.

Pterodactyloidea incertae sedi

$$
\begin{aligned}
& \text { Morrison Formation, } \\
& \text { Dry Mesa quarry, } \\
& \text { Montrose County, } \\
& \text { Colorado, USA }
\end{aligned}
$$

\section{Non dsungaripteroid}

'Santandactylus spixi'

\section{Morrison Formation, \\ Late Jurassic}

USA

\section{La Cruz Formation, \\ San Luis, Argentina}

Lotena Formation,

Arroyo Picún Leufú,

Province of Neuquén

Argentina

bauxite deposits, Cornet,

Oradea, Romania

Santana Formation,

Chapada do Araripe.

Brazil
Early Cretaceous

Middle Jurassic

Early Cretaceous

Late Jurassic

Early Cretaceous
Fragmentary remains of a single individual

A complete tibiotarsus

Pelvis and paris of associated femora

fragmentary jaw

wing phalanx one

Incomplete forelimb
Harris \& Carpenter 1996

\section{a carpenter 1996} Bonaparte \& Sanchez 1975 ,
Galton 1980

Casamiquela 1975 ,

Bonaparte, 1978,

Galton 1980,

Unwin 1996

see refs in Benton et al. 1997

Jensen \& Ostrom 1977

Wellnhofer 1985, Bennett 1989, 1994, Unwin and Lü 1997
The humerus (Harris and Carpenter 1996, fig. 2) is remarkably similar to that of dsungaripterids

The tibiotarsus is similar to that of dsungaripteroids (Galton 1980), but this assignment requires confirmation

Similarities with dsungaripteroids were noted by Unwin (1996): this material requires further study

The wing phalanx one is recurved forwards as in dsungaripteroids

The carpal morphology of this form is widely distributed in pterodactyloids and cannot be used to support assignment to Dsungaripteroidea (see Unwin \& Lü 1997) 